\title{
Depletion of soil organic carbon and nitrogen under Pinus taeda plantations in Southern Brazilian grasslands (Campos)
}

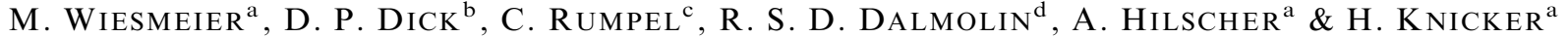 \\ ${ }^{\mathrm{a}}$ Lehrstuhl für Bodenkunde, Department für Ökologie und Ökosystemmanagement, Wissenschaftszentrum Weihenstephan für Ernährung, \\ Landnutzung und Umwelt, Technische Universität München, D-85350 Freising-Weihenstephan, Germany, ' Instituto de Quimica, UFRGS, \\ Avenida Bento Gonçalves, 9500, CEP 91501-970, Porto Alegre, RS, Brazil, ${ }^{\mathrm{c}}$ CNRS, Laboratoire de Biogeochimie des Milieux \\ Continentaux, (UMR CNRS, INRA, Université Paris VI, IRD), Campus AgroParisTech, Batiment EGER, 78850 Thiverval-Grignon, \\ France, and ${ }^{\mathrm{d}}$ Departamento de Solos, UFSM, Campus Universitário, Santa Maria, RS, CEP 97105-900, Brazil
}

\begin{abstract}
Summary
Establishment of pine (Pinus spp.) plantations on grasslands could increase carbon (C) sequestration to counteract increased atmospheric carbon dioxide concentrations. In the grasslands of the southern Brazilian highland (Campos), large areas have been converted to Pinus plantations over the last 30 years. In order to assess the impact of this land-use change on the amount and composition of soil organic matter (SOM), we investigated a grassland pasture site $(\mathrm{G})$, and both an 8-year-old (P8) and a 30-year-old (P30) plantation with Pinus taeda. Soil samples down to $45 \mathrm{~cm}$ were analysed for texture, $\mathrm{pH}$, soil organic carbon (SOC) and total nitrogen $\left(\mathrm{N}_{\text {tot }}\right)$ concentrations. Chemical composition of SOM was determined by using cross-polarization magic angle spinning (CPMAS) ${ }^{13} \mathrm{C}$ NMR spectroscopy. We analysed for stable $\mathrm{C}$ isotope $\left(\delta^{13} \mathrm{C}\right)$ and assessed the lignin composition by $\mathrm{CuO}$ oxidation. Additionally, contents of pyrogenic organic material (PyOM) were determined because the Campos is regularly burnt. Both pine plantations revealed relatively small SOC concentrations in the mineral soil of $72.6 \mathrm{mg} \mathrm{g}^{-1}$ (P8) and $56.8 \mathrm{mg} \mathrm{g}^{-1}(\mathrm{P} 30)$ and $\mathrm{N}_{\text {tot }}$ concentrations of $4.0 \mathrm{mg} \mathrm{g}^{-1}$ (P8) and $2.9 \mathrm{mg} \mathrm{g}^{-1}$ (P30) for the A horizon, while grassland showed significantly $(P<0.01)$ larger contents of $100.2 \mathrm{mg} \mathrm{g}^{-1}$ for SOC and $5.9 \mathrm{mg} \mathrm{g}^{-1}$ for $\mathrm{N}_{\text {tot }}$. Accumulation of litter layers suggests decreased input of organic material into the mineral soil under pine, which was confirmed by the $\delta^{13} \mathrm{C}$ values and lignin composition. Smaller contents of vanillyl- (V), syringyl- (S), and cinnamyl (C)-phenols, smaller ratios of S/V and $\mathrm{C} / \mathrm{V}$, and smaller ratios of acidic to aldehydic forms of $\mathrm{V}$ and $\mathrm{S}$ phenols indicated a high degree of decomposition of residual grass-derived SOM in the upper part of the mineral soil $(0-10 \mathrm{~cm})$ under pine plantations. This was confirmed by CPMAS ${ }^{13} \mathrm{C}$ NMR spectroscopy, showing an increasing Alkyl $\mathrm{C} / \mathrm{O}-\mathrm{Alkyl} \mathrm{C}$ ratio at the same depth. No significant changes in the contents of PyOM could be detected, but all sites tended to show the greatest concentrations at deeper soil depths $>15 \mathrm{~cm}$, indicating a vertical relocation of PyOM. The results suggest that decomposition of residual SOM originating from grassland species contributes to the decrease of SOC and $\mathrm{N}_{\text {tot }}$ and to an acidification in the topsoil under pine plantations. We also suggest that slow litter decomposition and incorporation and the absence of fires at the plantations are additional reasons for the reduced amount of SOM. Depletion of SOM and the acidification of the topsoil may reduce the availability and supply of nutrients and diminish the $\mathrm{C}$ sequestration potential of the mineral soil.
\end{abstract}

\section{Introduction}

Plantation forests established on agricultural land are regarded as an important means to reduce atmospheric carbon dioxide $\left(\mathrm{CO}_{2}\right)$

Correspondence: M. Wiesmeier. E-mail: wiesmeier@wzw.tum.de Received 16 May 2008; revised version accepted 27 November 2008 concentrations (IPCC, 2007). Although it is obvious that the tree biomass produced presents a large sink for atmospheric carbon $(\mathrm{C})$, there is considerable uncertainty regarding changes in soil $\mathrm{C}$ stocks. Both increased and decreased soil $\mathrm{C}$ have been reported in numerous studies, most of which focused on afforestation in temperate regions (e.g. Parfitt et al., 1997; Guo \& 
Gifford, 2002; Ross et al., 2002). However, when considering different tree species, it seems that under hardwoods soil $\mathrm{C}$ generally increases, whereas under plantations with softwoods, particularly Pinus species, soil organic C (SOC) is lost (Guo \& Gifford, 2002; Paul et al., 2002). Several mechanisms have been discussed to account for this decline, but few studies provide objective evidence for the processes assumed to occur. In tropical and subtropical regions, where large parts of natural savannas and grasslands were converted to plantations with Pinus spp. during the previous 30 years (Le Maitre, 1998), data on the impact of these afforestations on SOM properties are scarce (Lilienfein et al., 2000; Zinn et al., 2002). The grasslands in the south Brazilian highlands (Figure 1), commonly referred to as Campos, belong to a region where large areas of grassland under pasture were afforested, mainly with Pinus spp. (Goldammer, 1993). In contrast to the adjacent Pampa biome, the Campos is a mosaic of natural grasslands and different forest types and occupies approximately 13.7 million ha (Nabinger et al., 2000). As Overbeck et al. (2007) recently pointed out, large parts of the Campos have been transformed to pine plantations because economic returns are greater than for cattle production. Therefore, the Campos area is decreasing at a rate of 135000 ha per year (Carvalho, 2006) and has lost approximately $25 \%$ of its area in the last 30 years as a consequence of conversion to cash crops and pine plantations (Nabinger et al., 2000; Overbeck et al., 2007). However, no studies concerning the impacts of these land use changes on soil properties are available.

As soil organic matter (SOM) has a particular importance for soil fertility in tropical and subtropical soils, any decline would result in a significant degradation of these soils. Recent studies of the Campo area clearly indicated that such a decline of SOC and total nitrogen $\left(\mathrm{N}_{\text {tot }}\right)$ can be induced by stopping prescribed burning at the end of the winter (Knicker et al., 2008a).
Other studies demonstrate that burning is an important process to maintain SOC contents in grasslands (Lal, 2004; Chen et al., 2005; Dai et al., 2006). However, no studies are available that report to what extent the decline of SOM is reduced by plantation of pines after burning has been stopped. Therefore, we investigated the effect of afforestation with Pinus taeda on former grassland from the Campos in Rio Grande do Sul, Brazil. Both 8-year-old (P8) and 30-year-old (P30) pine plantations were sampled and the chemical composition, analysed by solid-state ${ }^{13} \mathrm{C}$ NMR and determination of stable isotope ratios $\left(\delta^{13} \mathrm{C}\right)$ and lignin oxidation products, was compared with that of native grassland soil $(\mathrm{G})$. The content of pyrogenic organic matter (PyOM) was measured by chemical oxidation with acid potassium dichromate. The hypotheses were: that (i) there is a change in the concentration of SOC and composition of SOM as a result of afforestation and (ii) that there are direct effects caused by planting pines and indirect effects induced by the absence of vegetation fires in pine plantations. We investigated the mechanisms responsible for the possible changes.

\section{Materials and methods}

\section{Study area and sampling}

The research was conducted in the highlands (Planalto-Campos de Cima da serra) in the northeast of Rio Grande do Sul, southern Brazil $\left(28^{\circ} 35^{\prime}-39^{\prime} \mathrm{S}, 49^{\circ} 51^{\prime}-57^{\prime} \mathrm{W}\right)$ at an average altitude of $1280 \mathrm{~m}$ above sea level. Climate is characterized as a transition between subtropical and temperate conditions, with a mean annual temperature of $14.5^{\circ} \mathrm{C}$, large precipitation (annual values of 1800-2000 mm), a short dry period of less than 2 months in the summer and up to 15 days with frost during winter (Nimer, 1979).

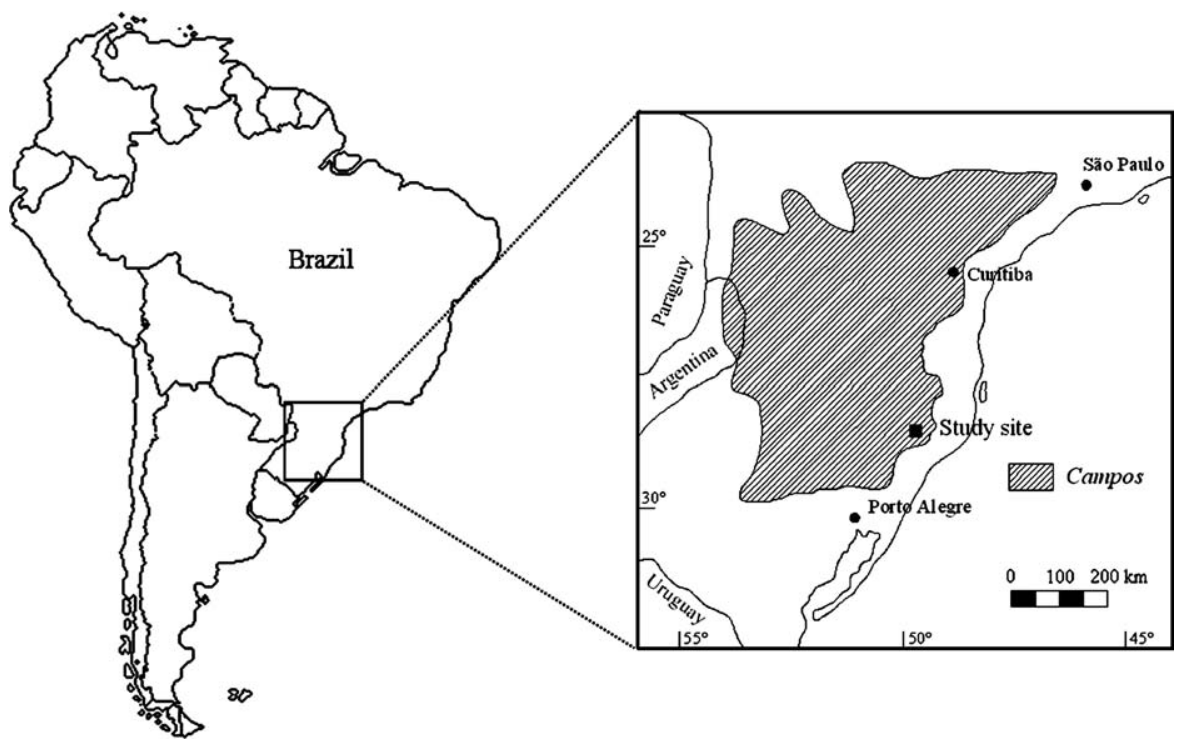

Figure 1 Map of South America showing the location of the Campos (adapted after Hueck, 1966) and the study area. 
The soils are classified as Leptosols with Ah thickness of $25 \mathrm{~cm}$ and as Umbrisols with Ah of $30 \mathrm{~cm}$ (IUSS Working Group WRB, 2006), derived from acid volcanic rocks. The diverse vegetation (3000-4000 phanerophytic species) of the grassland in the south Brazilian highland is composed of tropical, continental and temperate species belonging to the families Poaceae, Cyperaceae, Asteraceae, Apiaceae, Fabaceae and Eriocaulaceae, with a large proportion of C4-grasses (Behling, 1997). For the grassland studied, fire was used as a management tool approximately every 2 years after the winter season to remove grass and shrub biomass, to stimulate the regrowth after the winter and to supply nutrients. Further information concerning the Campos region is presented by Overbeck et al. (2007).

Soil material was taken from the A horizon of a grassland pasture (site G) and two former grassland sites, that were converted into Pinus taeda plantations 8 (site P8) and 30 years (site P30) before sampling. Samples were split into depth increments of $0-5 \mathrm{~cm}, 5-10 \mathrm{~cm}, 10-15 \mathrm{~cm}, 15-25(30) \mathrm{cm}$ and from 25 (30) to $45 \mathrm{~cm}$ (C horizon). At each site, four profiles separated by a distance of $10-30 \mathrm{~m}$ were sampled. Additionally, grass material $(\mathrm{Gr})$ from site $\mathrm{G}$, and also pine needle litter $(\mathrm{N})$ and material from the Oe and Oa horizon of site P8 were collected. No fires occurred after afforestation and the grassland area was last burnt 9 months before sampling. At all sites, the slopes were $<3 \%$. For determination of the bulk density (BD), undisturbed soil samples were taken from two locations with $6 \mathrm{~cm}$ diameter metal cores. Before grinding, the samples were air-dried and passed through a $2 \mathrm{~mm}$ sieve.

\section{Determination of soil properties}

For the analyses of soil texture, two samples $(<2 \mathrm{~mm})$ from each site were oxidized with $\mathrm{H}_{2} \mathrm{O}_{2}$ to remove organic material. The remaining material was dispersed with $\mathrm{Na}_{4} \mathrm{P}_{2} \mathrm{O}_{7}$ and shaken for at least 16 hours, followed by wet sieving to isolate sand fractions (2000-63 $\mu \mathrm{m})$. To determine silt and clay fractions, approximately $3 \mathrm{~g}$ of the $<63 \mu \mathrm{m}$ fraction was suspended in deionized water with $\mathrm{Na}_{4} \mathrm{P}_{2} \mathrm{O}_{7}$ and followed by ultrasonication for 3 minutes with $75 \mathrm{~J} \mathrm{ml}^{-1}$. Afterwards, the distribution of silt $(63-2 \mu \mathrm{m})$ and clay $(<2 \mu \mathrm{m})$ fractions was obtained by measuring the X-ray absorption of the soil-water suspension during sedimentation of the soil particles with a Micrometrics Sedigraph 5100 (Norcross, GA, USA).

The bulk density of the A-horizon was quantified for two samples from each site with the mass of the oven-dry soil $\left(105^{\circ} \mathrm{C}\right)$ divided by the core volume (Hartge \& Horn, 1989). Soil $\mathrm{pH}$ values for four samples from each site were measured in $0.01 \mathrm{M} \mathrm{CaCl}_{2}$ at a soil/solution ration of 1:2.5 at room temperature. SOC and $\mathrm{N}_{\text {tot }}$ in four samples from each site were determined in duplicates by dry combustion on a CHN autoanalyser (CHN NA 1500, Carlo Erba, Rodano, Italy). As all samples were free of carbonate, the measured $\mathrm{C}$ concentrations represent the SOC concentrations.
Analysis of the $\delta^{13} C$ isotope ratios

The stable $\mathrm{C}$ isotope ratios were measured for four samples from each site by a $\mathrm{CHN}$ auto analyser coupled to an isotope ratio mass spectrometer (VG Sira 10, VG Isotech, Middlewich, UK). The laboratory reference was calibrated against the international standard Vienna Pee Dee Belemnite (VPDB). Carbon isotope ratios were expressed in the delta notation for $\delta^{13} \mathrm{C}$ with units of per thousand $(\%)$, which is the difference in the ${ }^{13} \mathrm{C} /{ }^{12} \mathrm{C}$ ratio between a sample and the VPDB standard:

$$
\delta^{13} C=\left(\frac{\left({ }^{13} C /{ }^{12} C\right)_{\text {sample }}}{\left({ }^{13} C /{ }^{12} C\right)_{V P D B}}-1\right) \times 1000 .
$$

\section{Lignin quantitative analysis}

Lignin contents were analysed for two samples from each site using a modified method of the alkaline $\mathrm{CuO}$ oxidation method (Hedges \& Ertel, 1982). Approximately $200 \mathrm{mg}$ or $50 \mathrm{mg}$ of soil and plant material, respectively, were placed in Teflon vessels and oxidized with $15 \mathrm{ml} 2 \mathrm{M} \mathrm{NaOH}, 250 \mathrm{mg} \mathrm{CuO}, 50 \mathrm{mg}$ $\mathrm{Fe}\left(\mathrm{NH}_{4}\right)_{2}\left(\mathrm{SO}_{4}\right)_{2} \cdot 6 \mathrm{H}_{2} \mathrm{O}$ and $50 \mathrm{mg}$ glucose in a pressure bomb (Groteklaes, Jülich, Germany) at $172^{\circ} \mathrm{C}$ for 2 hours under a $\mathrm{N}_{2}$ atmosphere. Ethylvanillin was added after oxidation as an internal standard in order to control the recovery of lignin monomers, which is usually in the range of $60-75 \%$ (Dignac et al., 2005). The solution was quantitatively transferred to glass beakers, adjusted to $\mathrm{pH} 1.8-2.2$, and the generated lignin-derived phenols were cleaned by $\mathrm{C} 18$ columns (International Sorbent Technology, Hengoed, UK). The eluate was dried under $\mathrm{N}_{2}$ and silylated for gas chromatographic analysis. Determination of $\mathrm{CuO}$ oxidation products was carried out with a HP GC 6890 gas chromatograph, equipped with a SGE BPX5 column and a flame ionization detector (FID) in the split mode (1:10). The oven temperature was programmed from $100^{\circ} \mathrm{C}$ (held for 2 minutes), to $172^{\circ} \mathrm{C}$ with a linear increase of $8^{\circ} \mathrm{C} \mathrm{min}{ }^{-1}$, and to $184^{\circ} \mathrm{C}$ at a rate of $4^{\circ} \mathrm{C} \mathrm{min}{ }^{-1}$. The final temperature of $300^{\circ} \mathrm{C}$ was reached at a rate of $10^{\circ} \mathrm{C} \mathrm{min}^{-1}$.

$\mathrm{CuO}$ oxidation yields a suite of phenolic oxidation products composed of vanillyl (V), syringyl (S) and cinnamyl (C) units with aldehydic, ketonic and acidic side chains. V-type phenols are derived from coniferyl alcohol that is generated from gymnosperm lignin (Kögel-Knabner, 2002). They consist of concentrations of vanillin, acetovanillone and vanillic acid. S-type phenols are the sum of syringaldehyde, acetosyringone and syringic acid and originate from sinapyl alcohol units. In angiosperms, the lignin is built up from equal amounts of coniferyl and sinapyl alcohol (Johansson et al., 1986). C-type compounds consist of ferulic and p-coumaric acid components.

\section{Solid-state CPMAS ${ }^{13}$ C NMR spectroscopy}

Prior to the NMR spectroscopic analysis, two samples from each site were enriched in SOM by depleting the paramagnetic 
components by removing mineral components with hydrofluoric acid (HF) (Gonçalves et al., 2003). For each sample, $10-15 \mathrm{~g}$ of ground soil material was weighed into $100 \mathrm{ml}$ plastic bottles and $50 \mathrm{ml}$ of $10 \% \mathrm{HF}$ solution was added. After shaking for 2 hours, the samples were centrifuged for 10 minutes at $3008 \mathrm{~g}$ and the supernatant was discarded. This procedure was repeated five times and after this the samples were washed with $50 \mathrm{ml}$ deionized water to remove residual $\mathrm{HF}$ and freeze-dried.

The solid-state cross-polarization magic angle spinning (CPMAS) ${ }^{13} \mathrm{C}$ NMR spectra were obtained on a Bruker DSX 200 spectrometer (Karlsruhe, Germany) operating at a ${ }^{13} \mathrm{C}$ resonance frequency of $50.3 \mathrm{MHz}$. Demineralized samples were packed into zirconium dioxide rotors with a diameter of $7 \mathrm{~mm}$ and spun with $6.8 \mathrm{kHz}$ at the magic angle. All measurements were carried out with a ramped ${ }^{1} \mathrm{H}$ pulse during a contact time of $1 \mathrm{~ms}$ to avoid Hartmann-Hahn mismatches. Between 5000 and 300000 scans with pulse delays between 250 and $300 \mathrm{~ms}$ were applied. Before Fourier transformation, line broadenings of $50-100 \mathrm{~Hz}$ were used to improve the signal-to-noise ratios. The relative distribution of $\mathrm{C}$ forms in different structures was determined by integrating the signal intensity in various chemical shift regions assigned to carboxyl/carbonyl/amide C (220-160 p.p.m.), aromatic/olefinic C (160-110 p.p.m.), O-alkyl C (110-60 p.p.m.), N-alkyl/methoxyl C (60-45 p.p.m.) and alkyl C (45-0 p.p.m.). Because of insufficient averaging of the chemical shift anisotropy at a spinning speed of $6.8 \mathrm{kHz}$, spinning side bands of the aromatic $\mathrm{C}$ signal (140-110 p.p.m.) and the carboxyl C signal (220-160 p.p.m.) occurred at a frequency distance of the spinning speed on both sides of the central signal. They were accounted for by adding their intensities to that of the parent signal as described in Knicker et al. (2005). One side band of the carboxyl $\mathrm{C}$ is found in the region 276-323 p.p.m. Assuming that the second side band for carboxyl C between 0 and 45 p.p.m. is equal in size, the integral of the side band between 276 and 323 p.p.m. was doubled and added to the carboxyl signal (160-220 p.p.m.), but subtracted from the intensity of the alkyl $\mathrm{C}$ region $(0-45$ p.p.m.). The chemical shift scale was referenced to tetramethylsilane ( $=0$ p.p.m.) and adjusted with glycine (COOH; 172.8 p.p.m.).

\section{Determination of pyrogenic organic material (PyOM)}

For quantification of PyOM, a modified method of chemical oxidation with acid dichromate (Wolbach \& Anders, 1989) followed by solid-state CPMAS ${ }^{13} \mathrm{C}$ NMR spectroscopy of the chemical oxidation resistant elemental C (COREC) was used according to the method of Knicker et al. (2007, 2008b). For two samples from each site approximately $200 \mathrm{mg}$ of plant material or $500 \mathrm{mg}$ of HF-treated soil samples were weighed into $100 \mathrm{ml}$ plastic bottles and oxidized with $50 \mathrm{ml}$ of $0.1 \mathrm{M}$ $\mathrm{K}_{2} \mathrm{Cr}_{2} \mathrm{O}_{7} / 2 \mathrm{M} \mathrm{H}_{2} \mathrm{SO}_{4}$ solution for 6 hours at $60^{\circ} \mathrm{C}$ in an ultrasonic bath. Afterwards, the oxidation residues were washed five times with deionized water and freeze-dried. Determina- tion of the $\mathrm{C}$ concentration of the oxidized sample was carried out by dry combustion on a Vario Max CNS elemental analyser (Hanau, Germany) and COREC was expressed in percentage of the initial $\mathrm{C}$ content after mass balance calculation. The COREC content obtained for each sample was multiplied with the relative intensity of the aryl $\mathrm{C}$ region from solid-state CPMAS ${ }^{13} \mathrm{C}$ NMR spectra. A correction factor $f$ was applied to take account of PyOM losses induced by the chemical oxidation. This correction factor was obtained by calculating the contribution of the aromatic proportion of COREC to the total C of charcoal produced from the native vegetation at the study site (Knicker et al., 2008a). The resulting values represent an index for the content of PyOM (Rumpel et al., 2006; Knicker, 2007).

\section{Statistical analysis}

All statistical analyses were carried out using SPSS 16.0 (SPSS Inc., Chicago). Normal distribution and homogeneity of variances for the measured properties were tested by using the Kolmogoroff-Smirnoff test. To determine the significance of differences between the grassland and the pine plantations a one-way analysis of variance (ANOVA) combined with post hoc tests (LSD, Tukey and Scheffé) was applied.

\section{Results and discussion}

\section{Soil characteristics and $\mathrm{pH}$}

The A horizons at all sites showed comparable textures, with large clay contents between 46.5 and $58.2 \%$, silt contributions from 32.6 to $48.2 \%$ and small amounts of sand of 6.7 to $17.3 \%$ (Table 1). Topsoils had relatively small bulk densities between 0.72 and $0.77 \mathrm{~g} \mathrm{~cm}^{-3}$, which is in the range reported for adjacent grassland soils from the Campos (Dümig et al., 2007). For the layer between 0 and $5 \mathrm{~cm}$, the $\mathrm{pH}$ was 4.1 for the grassland soil. This value significantly $(P<0.01)$ decreased to 3.7 in the topsoil of the 8 year-old plantation and to 3.6 at the 30 yearold plantation, which is lower than that recently determined for Campo sites at which burning had stopped c. 22 years ago (Knicker et al., 2008b). These changes were not detected at depth.

Acidification of the topsoil after conversion of grasslands to forests with Pinus species is a common phenomenon throughout the world (e.g. in New Zealand (Ross et al., 2002), Ecuador (Farley \& Kelly, 2004) and in the Cerrado region in Brazil (Lilienfein et al., 2000)). The acidification of topsoils may be ascribed to the input of pine needle residues, which had a lower $\mathrm{pH}$-value of 3.6 compared with grass ( $\mathrm{pH}$ of 4.2 ). As well as the direct input of organic acids from the coniferous litter through leaching, a decrease in the $\mathrm{pH}$-value can be induced by increased soil respiration and enhanced nitrification coupled with net nitrate losses, as frequently observed after afforestation with pine (Parfitt et al., 1997; Scholes \& Nowicki, 1998). 
Table 1 Soil texture, bulk density $(\mathrm{BD}), \mathrm{C} / \mathrm{N}$ ratio and $\mathrm{pH}$ values of the studied samples (Standard deviation $( \pm)$ of four replications)

\begin{tabular}{|c|c|c|c|c|c|c|c|c|}
\hline Location & Horizon & $\begin{array}{l}\text { Depth } \\
\text { /cm }\end{array}$ & $\begin{array}{l}\text { Clay } \\
/ \%\end{array}$ & $\begin{array}{l}\text { Silt } \\
/ \%\end{array}$ & $\begin{array}{l}\text { Sand } \\
/ \%\end{array}$ & $\begin{array}{c}\mathrm{BD} \\
/ \mathrm{g} \mathrm{cm}^{-3}\end{array}$ & $\mathrm{C} / \mathrm{N}$ & $\mathrm{pH}\left(\mathrm{CaCl}_{2}\right)$ \\
\hline \multirow[t]{5}{*}{ G (Grassland) } & $\mathrm{Ah}$ & $0-5$ & 51.2 & 42.0 & 6.7 & 0.73 & $16.6 \pm 0.4$ & $4.1 \pm 0.1$ \\
\hline & & $5-10$ & 53.1 & 37.0 & 9.9 & & $16.6 \pm 0.3$ & $4.0 \pm 0.1$ \\
\hline & & $10-15$ & 49.1 & 35.7 & 15.2 & & $17.5 \pm 0.3$ & $3.9 \pm 0.1$ \\
\hline & & $15-30$ & 47.2 & 35.6 & 17.3 & & $20.6 \pm 2.9$ & $4.1 \pm 0.1$ \\
\hline & $\mathrm{Cv}$ & $30+$ & & & & & $18.8 \pm 0.9$ & $4.2 \pm 0.0$ \\
\hline \multirow[t]{5}{*}{ P8 (Pinus taeda 8 years) } & $\mathrm{Ah}$ & $0-5$ & 58.1 & 35.0 & 6.9 & 0.77 & $18.9 \pm 0.9$ & $3.7 \pm 0.1$ \\
\hline & & $5-10$ & 58.2 & 34.0 & 7.8 & & $18.0 \pm 0.8$ & $3.9 \pm 0.1$ \\
\hline & & $10-15$ & 56.6 & 34.7 & 8.7 & & $18.1 \pm 0.6$ & $3.9 \pm 0.0$ \\
\hline & & $15-25$ & 55.6 & 32.6 & 11.8 & & $18.4 \pm 1.0$ & $4.0 \pm 0.0$ \\
\hline & $\mathrm{Cv}$ & $25+$ & 24.6 & 48.2 & 27.2 & & $20.0 \pm 9.3$ & $4.0 \pm 0.0$ \\
\hline \multirow[t]{7}{*}{ P30 (Pinus taeda 30 years) } & Oe & $15-6$ & & & & & 31.7 & 3.2 \\
\hline & $\mathrm{Oa}$ & $6-0$ & & & & & 33.1 & 2.5 \\
\hline & $\mathrm{Ah}$ & $0-5$ & 46.5 & 44.5 & 9.0 & 0.72 & $19.7 \pm 0.7$ & $3.6 \pm 0.1$ \\
\hline & & $5-10$ & 48.1 & 41.5 & 10.3 & & $18.8 \pm 0.5$ & $3.8 \pm 0.1$ \\
\hline & & $10-15$ & 49.4 & 40.2 & 10.4 & & $18.6 \pm 0.8$ & $3.9 \pm 0.1$ \\
\hline & & $15-25(30)$ & 47.4 & 40.8 & 11.9 & & $20.1 \pm 2.3$ & $4.0 \pm 0.1$ \\
\hline & $\mathrm{Cv}$ & $25(30)+$ & 30.2 & 39.0 & 30.8 & & $20.5 \pm 4.3$ & $4.0 \pm 0.1$ \\
\hline N (Pine needles) & & & & & & & 120.5 & 3.6 \\
\hline Gr (Grass) & & & & & & & 42.3 & 4.2 \\
\hline
\end{tabular}

\section{Alteration of organic $C$ and $N$ contents}

Compared with adjacent grasslands in South America (Alvarez \& Lavado, 1998) and other grassland ecosystems (e.g. Steffens et al., 2008), the A horizon of the Campos of our study area had large SOC and $\mathrm{N}_{\text {tot }}$ contents of, respectively, $136 \mathrm{mg} \mathrm{g}^{-1}$ and $8.2 \mathrm{mg} \mathrm{g}^{-1}$ in the topsoil $(0-5 \mathrm{~cm})$ decreasing to $63.4 \mathrm{mg}$ $\mathrm{g}^{-1}$ and $3.5 \mathrm{mg} \mathrm{g}^{-1}$ in depths of 15-25(30) $\mathrm{cm}$ (Figure 2). For the $\mathrm{C}$ horizon, values of $21.7 \mathrm{mg} \mathrm{g}^{-1}$ for SOC and $1.3 \mathrm{mg} \mathrm{g}^{-1}$ for $\mathrm{N}_{\text {tot }}$ were determined. Afforestation with Pinus taeda resulted in a significant $(P<0.01)$ decrease of SOC down to $88.6 \mathrm{mg} \mathrm{g}^{-1}$ and of $\mathrm{N}_{\text {tot }}$ to $4.7 \mathrm{mg} \mathrm{g}^{-1}$ in the top $5 \mathrm{~cm}$ after
8 years. Under P30, the SOC concentration of the $0-5 \mathrm{~cm}$ soil layer declined to almost half $\left(72.7 \mathrm{mg} \mathrm{g}^{-1}\right)$ of that in the $\mathrm{G}$ site. A large depletion was also observed for $\mathrm{N}_{\text {tot }}$ of $3.7 \mathrm{mg} \mathrm{g}^{-1}$. In comparison, stopping burning 22 years previously on adjacent grassland sites resulted in lower depletion of $\mathrm{C}$ and $\mathrm{N}$ to $89 \mathrm{mg} \mathrm{g}^{-1}$ and $7 \mathrm{mg} \mathrm{g}^{-1}$ in the top $5 \mathrm{~cm}$, but in comparable C concentrations at 15 to 25 (30) cm depth (Knicker et al., 2008a). Mean SOC concentrations of the A horizon were $28 \%$ and $43 \%$ smaller for P8 and P30, respectively, and mean $\mathrm{N}_{\text {tot }}$ concentrations $32 \%$ and $51 \%$ smaller when compared with the G treatment (Figure 3).
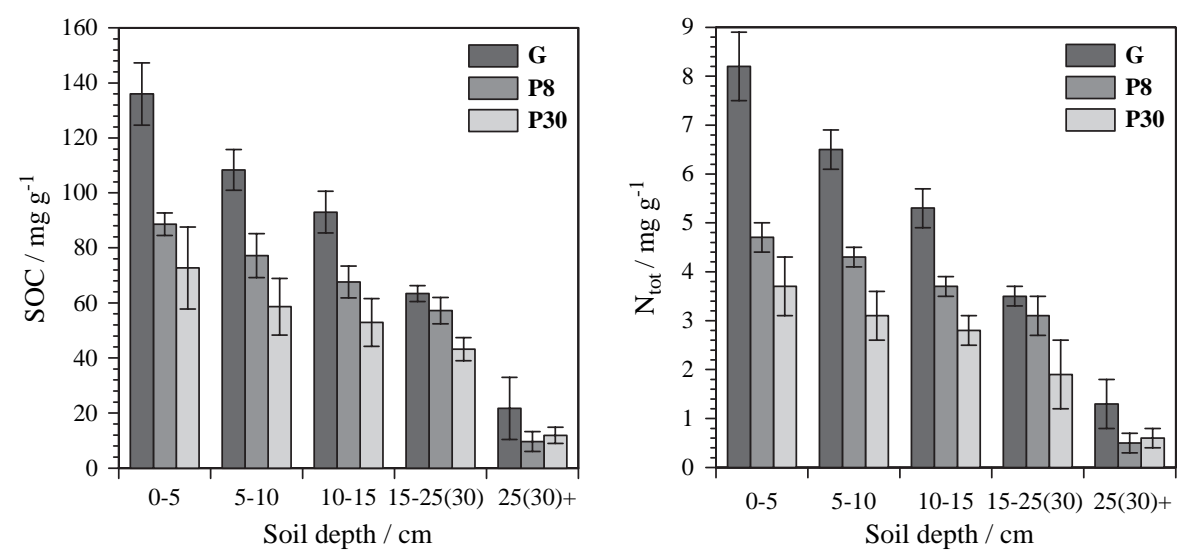

Figure 2 Content of SOC and $\mathrm{N}_{\text {tot }}\left(\mathrm{mg} \mathrm{g}^{-1}\right.$ ) of the grassland (G) and the pine plantations (P8, P30) at different soil depths. Error bars represent standard deviation $(n=4)$. 


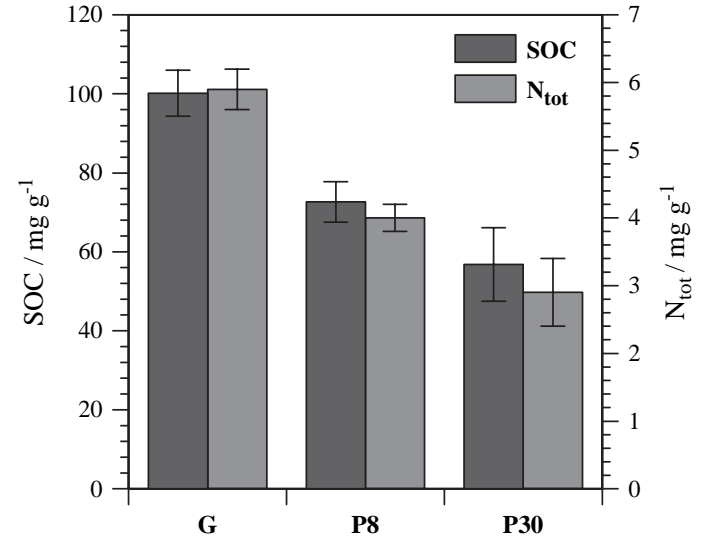

Figure 3 Mean SOC and $\mathrm{N}_{\text {tot }}$ concentrations $\left(\mathrm{mg} \mathrm{g}^{-1}\right.$ ) of the A horizon from the grassland $(\mathrm{G})$ and the pine plantations (P8, P30). Error bars represent standard deviation $(n=4)$.

Our results are in agreement with other findings of smaller SOC and $\mathrm{N}$ contents after conversion from grassland to Pinus spp. plantations. In general, SOC was $5-48 \%$ smaller in $7-23$ year old pine forests on former grassland and $\mathrm{N}$ was 14 to 47\% smaller (Paul et al., 2002; Ross et al., 2002; Zinn et al., 2002; Farley \& Kelly, 2004). A review of over 65 publications dealing with land use change from pasture to plantations with conifers (mainly Pinus radiata) showed that SOC decreased by $12 \%$ on average, whereas in areas with higher precipitation $(>1500 \mathrm{~mm}$ ) the depletion was greater (by 23\%) (Guo \& Gifford, 2002).

An important reason for the SOC and $\mathrm{N}_{\text {tot }}$ reduction in the mineral soil could be a change in the quantity and quality of organic matter input resulting from the vegetation change from mainly grass to pines. Although pines certainly contribute to the total litter production from their roots, the proportion of vegetation residue input derived from aboveground biomass is much greater when compared with grassland species with relatively large root/shoot ratios (Jackson et al., 1996). As pine litter is more recalcitrant than the easily degradable organic matter from grasses, litter decomposition rate is reduced and detrital inputs from pines accumulate on the soil surface. This was also observed in the plantations of our study sites, where organic surface layers were up to $15 \mathrm{~cm}$ thick. This greater recalcitrance can be caused by oversaturation in cavities of partly decomposed pine needles, chemical inhibitors, relatively large concentrations of lignin and other phenolic compounds and non-existent needledecomposer macrofauna (Goldammer, 1993; Scholes \& Nowicki, 1998; Zinn et al., 2002).

The greater reduction of $\mathrm{N}_{\text {tot }}$ compared with SOC could be attributed to $\mathrm{N}$-uptake by the pines and its immobilization into the above-ground biomass as was assumed for reduced $\mathrm{N}$ contents of soils under Pinus radiata plantations on former pastures in Australia (Birk, 1992). Furthermore, the suppression of $\mathrm{N}$-fixing grassland legumes by pines and leaching of mineralized $\mathrm{N}$ are likely to be important contributors to the increased $\mathrm{N}$-depletion, as well as a smaller $\mathrm{N}$-input after the change to litter with wider $\mathrm{C} / \mathrm{N}$ ratios.

In the grassland soil, the $\mathrm{C} / \mathrm{N}$ ratios increased with soil depth from 16.6 at $0-10 \mathrm{~cm}$ to 18.8 at $>30 \mathrm{~cm}$ (Table 1$)$. $\mathrm{C} / \mathrm{N}$ ratios of P8 were significantly $(P<0.05)$ greater in the first $10 \mathrm{~cm}$ with ratios of 18.0 to 18.9 , but there was no significant difference beneath this region. P30 also had significantly $(P<0.01)$ greater $\mathrm{C} / \mathrm{N}$ ratios of 19.7 and 18.8 at $0-5 \mathrm{~cm}$ and $5-10 \mathrm{~cm}$, respectively. Bearing in mind that the cessation of burning resulted in a clear decrease of the $\mathrm{C} / \mathrm{N}$ ratio to 13 (Knicker et al., 2008b), the marginal increase of this value for the material from the surface of the mineral soil from the afforested sites may be attributed to the alteration of litter material quality. Whereas for the vegetation of the Campos region a $\mathrm{C} / \mathrm{N}$ of 34 was determined (Knicker et al., 2008b), the grass material collected from the forest floor had a $\mathrm{C} / \mathrm{N}$ ratio of 42.3 and that of the pine needles was 120.5 .

\section{Changes of $\delta^{13} C$ isotope ratios after afforestation}

The $\delta^{13} \mathrm{C}$ values from the $\mathrm{G}$ site ranged from -14.4 to $-15.7 \%$, an isotopic signature that is characteristic of organic material derived from $\mathrm{C} 4$ plants with signatures ranging from approximately -9 to $-17 \%$ (Staddon, 2004). Plant $\delta^{13} \mathrm{C}$ values were $-14.6 \%$ for Campos vegetation (C4 photosynthesis) and $-29.3 \%$ for pine needles (C3 photosynthesis), resulting in a common isotopic difference of approximately $14 \%$ between C3 and C4 plants (Figure 4). Although organic surface layers (Oe and Oa horizons) from afforested sites exhibited characteristic $\delta^{13} \mathrm{C}$ values derived from $\mathrm{C} 3$ plants (pines), soil $\mathrm{C}$ isotope ratios had a $\mathrm{C} 4$ signature ranging from -14.2 to $-15.2 \%$. The only exception was the layer from $0-10 \mathrm{~cm}$ at $\mathrm{P} 30$, where $\delta^{13} \mathrm{C}$ had significantly $(P<0.01)$ smaller values of $-18.5 \%$ at

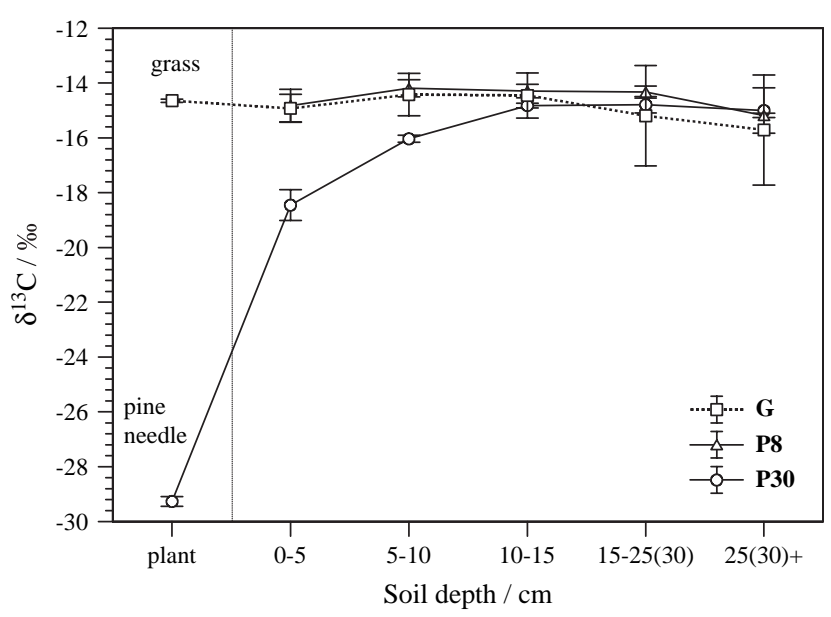

Figure $4 \delta^{13} \mathrm{C}$ values $(\%$ of plant samples (pine needle, grass) and different soil depths from the grassland $(\mathrm{G})$ and the pine plantations (P8, P30). Error bars represent standard deviation $(n=4)$. 
$0-5 \mathrm{~cm}$ and $-16.0 \%$ at $5-10 \mathrm{~cm}$. Carbon isotope ratios of the grassland were similar to those of soils in other $\mathrm{C} 4$ grasslands in southern Brazil (Martinelli et al., 1996; Dümig et al., 2007).

Alteration of inputs of organic material to pine litter had to continue for at least 15-30 years before even small effects on the SOM composition were detectable. Comparable time courses were also found by Dümig et al. (2007), who found no changes in 15 year-old pine plantations on former grassland. Although litter production rates to calculate $\mathrm{C}$ turnover were not available, the $\delta^{13} \mathrm{C}$ values obtained and $\mathrm{C} / \mathrm{N}$ ratios allow us to come to the conclusion that during the first two decades after afforestation, pine forest had no significant contribution to the SOM. Greater input of litter from C4 grasses can be excluded because growing of grass was limited through shading and mechanical displacement.

\section{Lignin degradation}

Figure 5 shows the sum of lignin-derived phenolic $\mathrm{CuO}$ oxidation products vanillyl, syringyl and cinnamyl units (VSC), which can be considered as an indicator of the relative amount of lignin (Hedges \& Mann, 1979). VSC values were normalized to SOC for soil and total plant $\mathrm{C}$ for plant samples, respectively, and expressed as $\mathrm{mg} \mathrm{VSC}^{-1} \mathrm{C}$. In general, the concentrations of VSC decreased with increasing soil depth at all sites, indicating a greater degree of decomposition of lignin in the deeper soil layers (Hedges \& Mann, 1979). The largest VSC content of $1.4 \mathrm{mg} \mathrm{g}^{-1} \mathrm{C}$ was determined in $\mathrm{G}$ at $0-5 \mathrm{~cm}$. P8 and $\mathrm{P} 30$ had significantly smaller concentrations of 1.1 and $1.0 \mathrm{mg} \mathrm{g}^{-1} \mathrm{C}$, respectively, although VSC-concentrations were greater for pine needles $\left(9.5 \mathrm{mg} \mathrm{g}^{-1} \mathrm{C}\right)$ than for grass $\left(4.3 \mathrm{mg} \mathrm{g}^{-1} \mathrm{C}\right)$. A comparable decrease of the VSC contents was also found in the topsoil of a forest with Pinus caribaea var. hondurensis in the adjacent savanna region (Cerrado) of Brazil (Zinn et al., 2002).

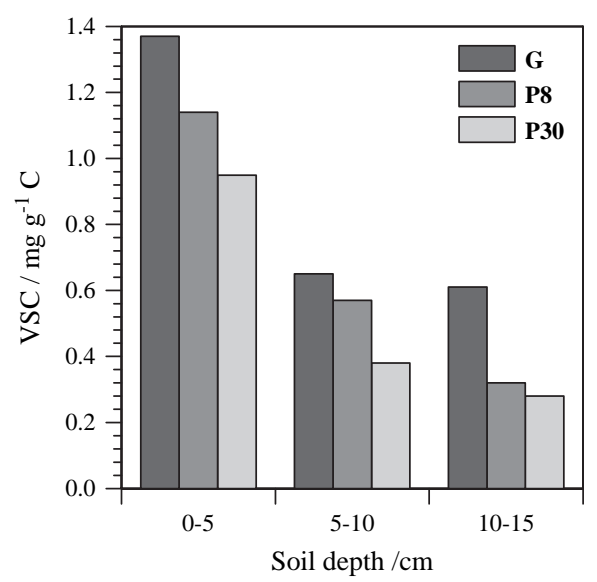

Figure 5 Concentrations of V-, S- and C-type phenols (VSC, $\mathrm{mg} \mathrm{g}^{-1}$ C) from the grassland $(\mathrm{G})$ and the pine plantations (P8, P30) at different soil depths (mean values of two replications).
The ratios of syringyl to vanillyl units $(\mathrm{S} / \mathrm{V})$ and cinnamyl to vanillyl units $(\mathrm{C} / \mathrm{V})$ provide information not only on the source of the lignin, but also about its state of decomposition because the stability against degradation is in the order $\mathrm{V}>\mathrm{S}>\mathrm{C}$ (Hedges \& Mann, 1979; Ziegler et al., 1986). The ratios of S/V and $\mathrm{C} / \mathrm{V}$ decreased at the $\mathrm{G}$ site with increasing soil depth, which is in accordance with an increasing degradation state of lignin in the deeper soil layers, already assumed from the declining VSC contents (Figure 6). Both afforested sites, on the other hand, showed an opposite trend with the smallest $\mathrm{S} / \mathrm{V}$ and $\mathrm{C} / \mathrm{V}$ ratio in the upper soil layers from 0 to $5 \mathrm{~cm}$ and 5 to $10 \mathrm{~cm}$. The older forested site (P30) had smaller ratios than the younger site (P8). Because the $\mathrm{S} / \mathrm{V}$ ratio is lower (approximately 1:13) for lignin produced from gymnosperms than from angiosperms with equal amounts of $\mathrm{S}$ and $\mathrm{V}$ phenols, and only non-woody vascular plant tissues produce C-type phenols (Hedges \& Mann, 1979), those observations could be explained by enhanced input of pine litter at the pine sites. Pine needles had much smaller ratios of $\mathrm{S} / \mathrm{V}$ and $\mathrm{C} / \mathrm{V}(0.067$ and 0.154 , respectively) compared with grass (0.414 and 0.777 , respectively). However, this interpretation contrasts with the data obtained from the $\mathrm{C}$ isotope analysis and the VSC concentrations, which indicated only minor inputs of fresh pine litter. Thus, the decreasing ratios probably result from a more advanced degradation state of lignin derived from grass residues still present in the forest soils. Between 10 and $15 \mathrm{~cm}$ depth no significant differences between G, P8 and P30 were found, demonstrating that the deeper soil layers were not yet affected by the vegetation change.

The ratio of acidic to aldehydic forms of vanillyl, $(\mathrm{Ac} / \mathrm{Al})_{\mathrm{V}}$, and syringyl, $(\mathrm{Ac} / \mathrm{Al})_{\mathrm{S}}$, are further indicators for the degree of lignin oxidation (Hedges \& Ertel, 1982; Ziegler et al., 1986) and allow an assessment of its origin from gymnosperms ((Ac/ $\left.\mathrm{Al})_{\mathrm{V}}\right)$ (i.e. Pinus spp. in our case) or angiosperms $\left((\mathrm{Ac} / \mathrm{Al})_{\mathrm{S}}\right)$ (i.e. grass in our case). $(\mathrm{Ac} / \mathrm{Al})_{\mathrm{V}}$ showed no significant difference between G, P8 and P30 in the topsoil from 0 to $5 \mathrm{~cm}$ and 5 to $10 \mathrm{~cm}$ and increased at all sites with soil depth (Figure 7). The latter finding is in accordance with an enhanced oxidation degree of the lignin residues depth. For the top $5 \mathrm{~cm},(\mathrm{Ac} / \mathrm{Al})_{\mathrm{S}}$ was greater at the forest sites compared with the grassland. This greater proportion of acidic compounds is direct evidence for an enhanced oxidation of grass-derived SOM in the topsoil of the pine plantations. In the deeper soil layers, no significant differences between the different locations were found.

\section{Chemical composition of SOM (CPMAS ${ }^{13} \mathrm{C} N M R$ spectroscopy)}

After HF treatment, all soil samples were enriched in SOC by a factor of 3.2 to 11.3 and in $\mathrm{N}_{\text {tot }}$ by a factor of 3.2 to 11.7 , whereas the greatest accumulation was at depth, especially in the $\mathrm{C}$ horizon. Recovery of SOC was between 51 and $78 \%$ for the $\mathrm{A}$ and 26 and $49 \%$ for the $\mathrm{C}$ horizon and for $\mathrm{N}_{\text {tot }} 53$ and $74 \%$ for the $\mathrm{A}$ and 19 and $53 \%$ for the $\mathrm{C}$ horizon, which is in 

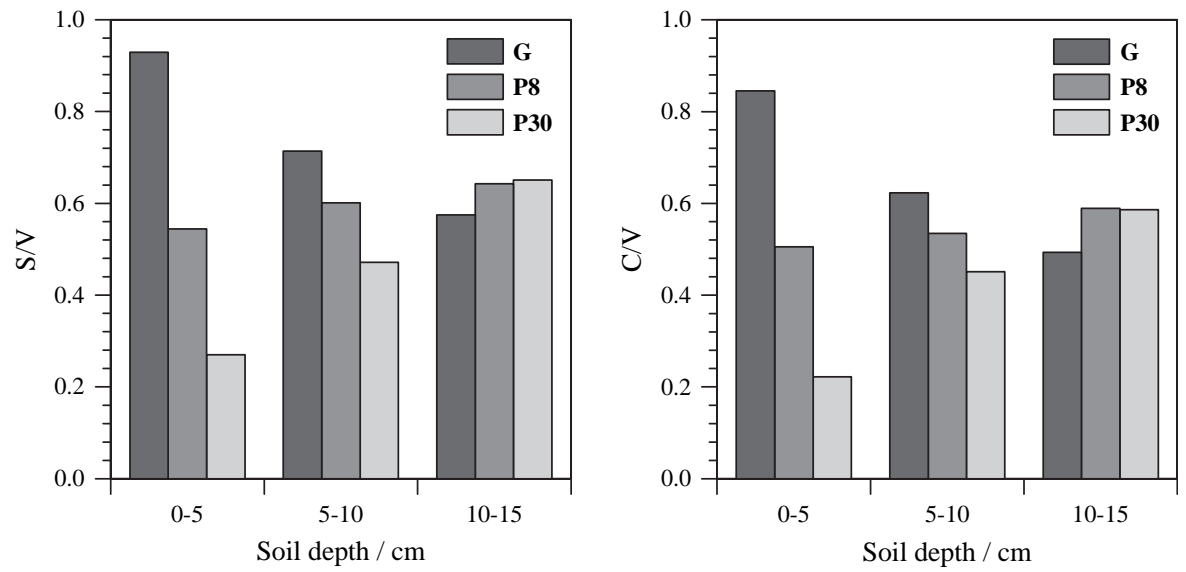

Figure 6 Ratios of syringyl-to-vanillyl phenols (S/V) and cinnamyl-to-vanillyl phenols (C/V) from the grassland (G) and the pine plantations (P8, P30) at different soil depths (mean values of two replications).

the range of losses during the HF treatments of the Campos soils of this region and of other studies (Gonçalves et al., 2003; Dieckow et al., 2005). For the detection of possible alterations of the original organic material as a consequence of the HF treatment, the factor R was calculated (Schmidt et al., 1997):

$$
\begin{aligned}
\mathrm{R}= & (\mathrm{C} / \mathrm{N} \text { before HF treatment }) / \\
& (\mathrm{C} / \mathrm{N} \text { after HF treatment }) .
\end{aligned}
$$

R-values of between 0.9 and 1.1 for all samples plus the fact that there were no major differences between the intensity distribution in solid-state ${ }^{13} \mathrm{C}$ NMR spectra of the grassland soils before and after HF-treatment (Knicker et al., 2008b) suggest that selective changes in the SOM did not occur during demineralization.

Table 2 lists the intensity distributions (\%) in the solid-state CPMAS ${ }^{13} \mathrm{C}$ NMR spectra of soil, litter and plant samples: representative spectra are shown in Figure 8. In all spectra, the greatest intensity was found in the chemical shift region between 60 and 110 p.p.m., which is probably assignable to O-alkyl C. The contribution of this C-class material decreased with depth and with increasing time from afforestation (i.e. in accordance with a preferential decomposition of carbohydrates and a relative decrease of the input of fresh litter residues into the upper mineral soil). The $\mathrm{N}$-alkyl $\mathrm{C}$ region from 45 to 60 p.p.m. showed no differences between the sites investigated.

In the top $10 \mathrm{~cm}$, the relative intensity in the region between 0 and 45 p.p.m., comprising signals from alkyl $\mathrm{C}$ in fatty acids, amino acids and alkane structures, increased slightly with time after afforestation. A comparable tendency can be observed for the region between 220 and 160 p.p.m., which is probably attributable to carboxylic $\mathrm{C}$. The alkyl $\mathrm{C} /$ carboxyl $\mathrm{C}$ ratio, however, remained at approximately 2 to 3 , demonstrating that accumulation of short-chain acids rather than the preferential preservation of long-chain lipids and alkane structures was responsible for the increase in alkyl C.
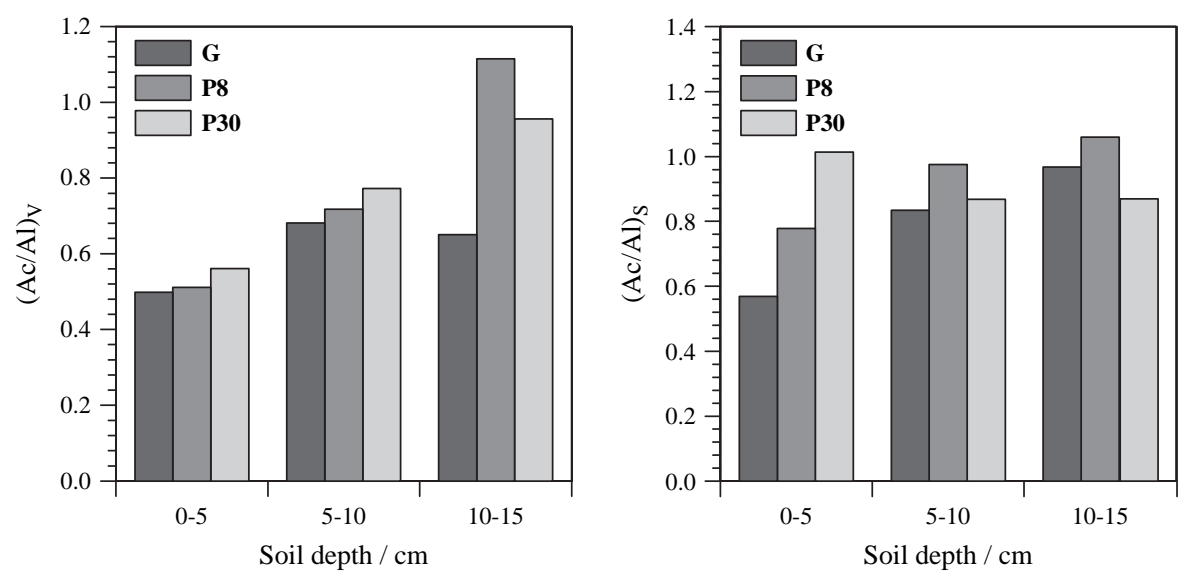

Figure 7 Ratios of acidic to aldehydic forms of vanillyl phenols $(\mathrm{Ac} / \mathrm{Al})_{\mathrm{V}}$ and syringyl phenols $(\mathrm{Ac} / \mathrm{Al})_{\mathrm{S}}$ from the grassland $(\mathrm{G})$ and the pine plantations (P8, P30) at different soil depths (mean values of two replications). 
Table 2 Relative signal distributions (\%) in the solid-state CPMAS ${ }^{13} \mathrm{C}$ NMR spectra of litter, plant and soil samples at different soil depths from the grassland $(\mathrm{G})$ and the pine plantations (P8, P30) (Mean values calculated from two replicates)

\begin{tabular}{|c|c|c|c|c|c|c|c|c|}
\hline Location & Horizon & $\begin{array}{l}\text { Depth } \\
/ \mathrm{cm}\end{array}$ & $\begin{array}{c}\text { Carboxylic C } \\
220-160 \text { p.p.m. }\end{array}$ & $\begin{array}{c}\text { Aromatic C } \\
160-110 \text { p.p.m. }\end{array}$ & $\begin{array}{c}\text { O-alkyl C } \\
110-60 \text { p.p.m. }\end{array}$ & $\begin{array}{c}\text { N-alkyl C } \\
60-45 \text { p.p.m. }\end{array}$ & $\begin{array}{c}\text { Alkyl C } \\
\text { 45-0 p.p.m. }\end{array}$ & Alkyl C/O-alkyl C \\
\hline \multirow[t]{5}{*}{ G (Grassland) } & \multirow[t]{4}{*}{$\mathrm{Ah}$} & $0-5$ & 9 & 16 & 43 & 9 & 23 & 0.54 \\
\hline & & $5-10$ & 11 & 18 & 39 & 9 & 23 & 0.59 \\
\hline & & $10-15$ & 12 & 19 & 39 & 8 & 22 & 0.56 \\
\hline & & $15-30$ & 13 & 23 & 34 & 8 & 22 & 0.65 \\
\hline & $\mathrm{Cv}$ & $30+$ & 15 & 27 & 30 & 8 & 20 & 0.67 \\
\hline \multirow[t]{5}{*}{$\mathbf{P 8}$ (Pinus taeda 8 years) } & \multirow[t]{4}{*}{$\mathrm{Ah}$} & $0-5$ & 12 & 19 & 37 & 8 & 24 & 0.65 \\
\hline & & $5-10$ & 14 & 20 & 37 & 8 & 21 & 0.57 \\
\hline & & $10-15$ & 14 & 21 & 36 & 8 & 21 & 0.58 \\
\hline & & $15-25$ & 17 & 23 & 34 & 7 & 19 & 0.56 \\
\hline & $\mathrm{Cv}$ & $25+$ & 16 & 29 & 30 & 8 & 17 & 0.57 \\
\hline \multirow[t]{7}{*}{$\mathbf{P 3 0}$ (Pinus taeda 30 years) } & Oe & $15-6$ & 12 & 19 & 37 & 9 & 23 & 0.62 \\
\hline & $\mathrm{Oa}$ & $6-0$ & 9 & 21 & 41 & 8 & 21 & 0.51 \\
\hline & \multirow[t]{4}{*}{$\mathrm{Ah}$} & $0-5$ & 12 & 21 & 31 & 9 & 27 & 0.87 \\
\hline & & $5-10$ & 13 & 21 & 32 & 8 & 26 & 0.82 \\
\hline & & $10-15$ & 13 & 23 & 32 & 8 & 24 & 0.75 \\
\hline & & $15-25(30)$ & 16 & 24 & 30 & 8 & 22 & 0.73 \\
\hline & \multirow[t]{3}{*}{$\mathrm{Cv}$} & $25(30)+$ & 14 & 27 & 29 & 8 & 22 & 0.76 \\
\hline $\mathbf{N}$ (Pine needles) & & & 3 & 17 & 58 & 7 & 15 & 0.26 \\
\hline Gr (Grass) & & & 9 & 18 & 48 & 8 & 17 & 0.35 \\
\hline
\end{tabular}

The alkyl C/O-alkyl C may be used as an index of the extent of decomposition of SOM (Baldock et al., 1992). However, this is only applicable if the source material remains constant, and processes leading to preferential sequestration of certain C-groups can be excluded. Such processes may include selective sorption onto soil minerals or preferential leaching of water soluble compounds. In the case of our study site, changes in the composition of the source material may be an additional cause for an alteration of this ratio. At site $\mathrm{G}$, the alkyl C/O-alkyl C ratio was 0.54 and 0.59 for the material from the depths 0 to
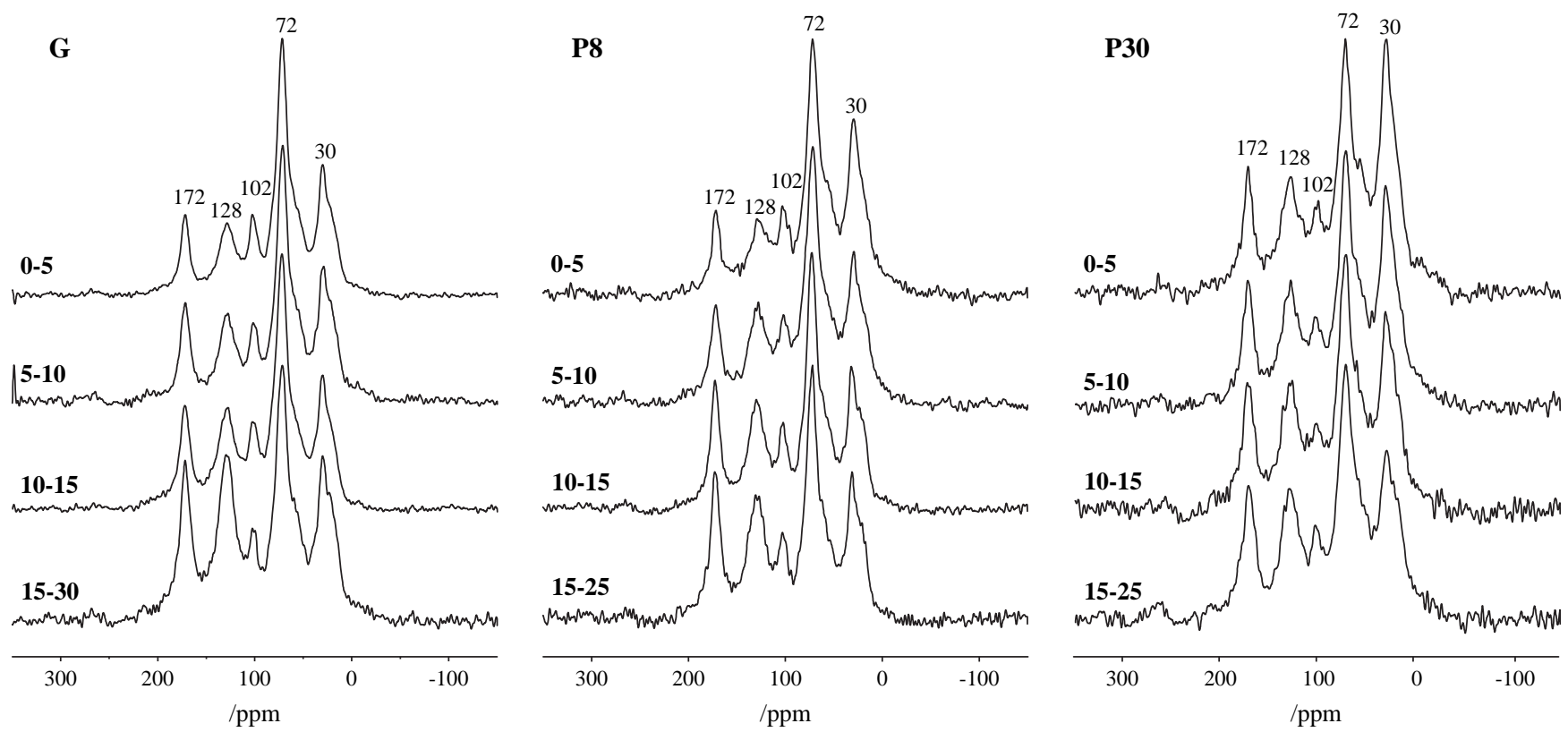

Figure 8 Solid-state CPMAS ${ }^{13} \mathrm{C}$ NMR spectra of the A horizon from the grassland (G) and the pine plantations (P8, P30) at different soil depths. 
$5 \mathrm{~cm}$ and 5 to $10 \mathrm{~cm}$ and increased to 0.65 and 0.57 for P8 and to 0.87 and 0.82 for P30, respectively (Table 2). The data collected so far do not support an enhanced input of pine litter into the mineral soils of P8 and at P30; only minor contributions of pine-derived SOM were found. These ratios are therefore in line with the assumption that over a time scale of a few decades, pine plantations of pines on grassland lead to an enhanced degradation of residual SOM in the mineral soil derived from the grass species. This conclusion is supported by the relatively comparable chemical composition of the SOM of the top $10 \mathrm{~cm}$ of P30 and of a Campos soil of the same area that remained unburnt for the last 22 years (Knicker et al., 2008b). For the latter, it was demonstrated that stopping burning had decreased the input of fresh litter from decaying grass plants. However, down to $30 \mathrm{~cm}, \mathrm{P} 30$ exhibited greater O-alkyl C and lower alkyl C contents with respect to the Campos soil profile, possibly because the deeper root system of pines allows the release of fresh exudates and thus the input of carbohydrate-rich organic matter at this depth.

The chemical shift region between 110 and 160 p.p.m. embraces signals of lignin and recalcitrant aromatic compounds such as pyrogenic organic matter (PyOM). For all sites, the relative contribution of aromatic $\mathrm{C}$ increased. Because we observed a decline in $\mathrm{CuO}$-oxidiation products down the soil profile, this is unlikely to be attributable to a selective preservation of lignin degradation products. However, because all sites were regularly burnt before changing to pine plantations, we tentatively suggest that the aromatic $\mathrm{C}$ enrichment with depth is caused by accumulation of PyOM.

\section{Content of pyrogenic organic material (PyOM)}

In general, PyOM accounted for 3.7 to $7.1 \%$ of organic $\mathrm{C}$, but there were no marked differences between the regularly burnt grassland and the pine plantations (Table 3). The observed
PyOM concentrations are in the range observed in other studies, which used the same method of chemical oxidation in combination with solid-state ${ }^{13} \mathrm{C}$ NMR spectroscopy (e.g. Rumpel et al., 2006). However, the spectra of the oxidized material also demonstrated large contributions in the alkyl $\mathrm{C}$ region (Figure 9) and therefore PyOM concentrations would be overestimated. Possibly, hydrophobic compounds such as plant waxes resisted the acid attack.

At all the sites investigated, PyOM contents tended to have greater amounts in deeper soil layers from 15 to $25(30) \mathrm{cm}$ with concentrations of 6.7 to $7.1 \%$ of organic C. Normally, the largest contents of PyOM should be located in the topsoil, because after burning, fire-affected SOM accumulates at the soil surface or in the first few $\mathrm{cm}$ of the soil. However, PyOM was relocated from the topsoil to the deepest part of the A horizon. This is in contrast to other studies, which demonstrated the graphite-like nature of PyOM and the associated chemical and physical recalcitrance against biological degradation (Schmidt \& Noack, 2000). There is rising evidence that PyOM is not as stable as assumed previously. Knicker et al. (2006) found significant charcoal contribution in the B horizon of a Spanish Cambisol only 2 years after a severe forest fire. This was explained by leaching of biochar residues that became water-soluble after oxidation and introduction of carboxylic groups. In a subtropical Acrisol from Brazil, the greatest amount of PyOM was found in the subsoil, and this was attributed to bioturbation (Dieckow et al., 2005). Such relocations may be explained by recently developed concepts that describe $\mathrm{PyOM}$ as a heterogeneous mixture of partly heat-altered biopolymers with domains of relatively small polyaromatic clusters, but with considerable substitution with $\mathrm{N}, \mathrm{O}$ and $\mathrm{S}$ functional groups (Knicker et al, 2007). Such structures offer enough areas for microbial attack and thus enable faster oxidation of PyOM, which then can be dissolved and relocated vertically.

Table 3 Content of chemical oxidation-resistant elemental carbon (COREC, \%), relative signal intensity (\%) of the aromatic C region in the solid-state CPMAS ${ }^{13} \mathrm{C}$ NMR spectra of COREC material and calculated PyOM concentrations (\%) from the grassland $(\mathrm{G})$ and the pine plantations (P8, P30) at different soil depths (Mean values calculated from two replicates)

\begin{tabular}{|c|c|c|c|c|c|}
\hline Location & Horizon & $\begin{array}{l}\text { Depth } \\
/ \mathrm{cm}\end{array}$ & $\begin{array}{c}\text { COREC } \\
/ \%\end{array}$ & $\begin{array}{c}\text { Aromatic C } \\
\qquad / \%\end{array}$ & $\begin{array}{c}\text { PyOM } \\
/ \%\end{array}$ \\
\hline \multirow[t]{4}{*}{ G (Grassland) } & \multirow[t]{4}{*}{$\mathrm{Ah}$} & $0-5$ & 23.5 & 15.7 & 3.7 \\
\hline & & $5-10$ & 27.2 & 14.4 & 3.9 \\
\hline & & $10-15$ & 28.5 & 17.2 & 4.9 \\
\hline & & $15-30$ & 32.0 & 21.0 & 6.7 \\
\hline \multirow[t]{4}{*}{ P8 (Pinus taeda 8 years) } & \multirow[t]{4}{*}{$\mathrm{Ah}$} & $0-5$ & 31.9 & 19.7 & 6.3 \\
\hline & & $5-10$ & 28.0 & 20.8 & 5.8 \\
\hline & & $10-15$ & 26.6 & 20.5 & 5.5 \\
\hline & & $15-25$ & 26.4 & 26.8 & 7.1 \\
\hline \multirow[t]{4}{*}{ P30 (Pinus taeda 30 years) } & \multirow[t]{4}{*}{$\mathrm{Ah}$} & $0-5$ & 28.0 & 17.1 & 4.8 \\
\hline & & $5-10$ & 29.7 & 20.0 & 5.9 \\
\hline & & $10-15$ & 24.2 & 24.7 & 6.0 \\
\hline & & $15-25(30)$ & 25.9 & 26.5 & 6.9 \\
\hline
\end{tabular}




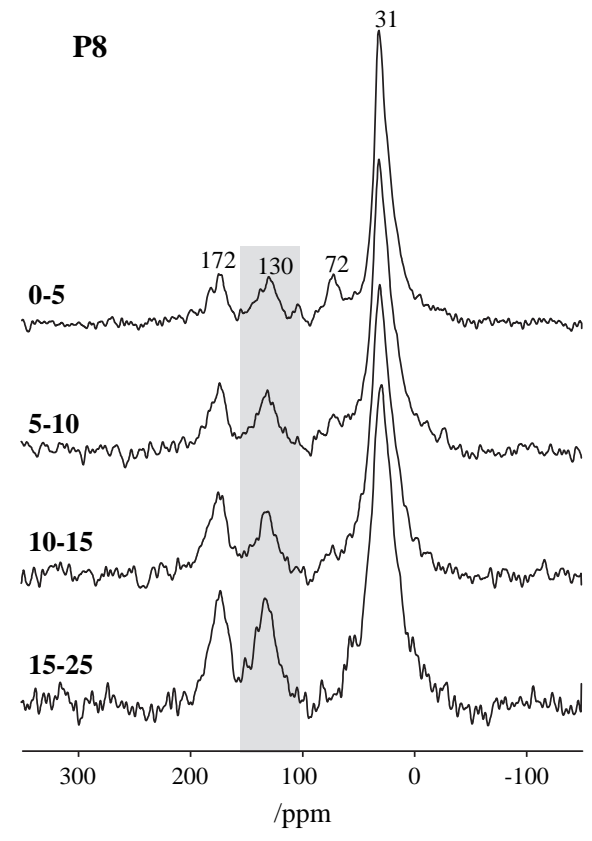

Figure 9 Solid-state CPMAS ${ }^{13} \mathrm{C}$ NMR spectra after chemical oxidation from the 8-year-old afforested site (P8) at different soil depths. The grey-coloured band shows the aromatic $\mathrm{C}$ region.

\section{Degradation of SOM and the effect of the cessation of burning}

The results of ${ }^{13} \mathrm{C}$ isotopic analysis, determination of lignin and CPMAS ${ }^{13} \mathrm{C}$ NMR spectroscopy indicated that throughout the soil profiles of the pine plantation SOM is mainly derived from grass residues. Even after 30 years, only a small impact of pine litter residues on SOM composition was present in the top $10 \mathrm{~cm}$. The low incorporation rate of pine litter may be explained by its high level of recalcitrance, leaving only partly degraded pine needles accumulating on the soil surface. Because of the decelerated input of fresh organic material, the SOC and $\mathrm{N}_{\text {tot }}$ losses caused by degradation cannot be balanced, thus resulting in decreasing SOM with a relatively high level of humification.

Any significant degradation of residual SOM was also assumed to be responsible for decreased SOC and $\mathrm{N}_{\text {tot }}$ contents in Pinus radiata plantations on former pastures from New Zealand, although there was no direct evidence for this (Davis, 1995; Parfitt et al., 1997). Low SOC concentrations at 0-5 cm depth from soils under forests with Pinus caribaea var. hondurensis in the Cerrado region of Brazil were explained by the site preparation with heavy ploughing to $20 \mathrm{~cm}$ and a low rate of pine needle litter input associated with acceleration of decomposition of remaining SOM formed under pastures (Zinn et al., 2002).

In addition, the observed decline is attributed to the absence of the formerly frequent vegetation fires. Such fires are, typically, of low intensity. The low heat conductivity of the mineral matter means that the heat intensity does not penetrate deeper then a few $\mathrm{cm}$ into the soil. Thus, such fires do not destroy the SOM in the mineral soil (Goldammer, 1993) and only the above-ground biomass is burnt, whereas the remaining roots die and contribute to the SOM. As below-ground biomass from grass and herb species accounts for a very large part of total biomass in grasslands, vegetation burning could be an important process in the accumulation of SOC and $\mathrm{N}$ in such soils (Knicker, 2007). Furthermore, there is a considerable C and N input from litter at the grassland sites because unburnt plant residues accumulate on the soil surface and the release of mineral nutrients from the ash allows the growth of herbs immediately after the fire. Thus, annual dry matter production is usually greater in regularly burnt than in unburnt grasslands (Lal, 2004). In tropical savannas of Australia, frequent burning caused greater SOC stocks, whereas fire exclusion led to smaller stocks, which was explained by a reduction in detrital input (Chen et al., 2005). Greater organic $\mathrm{C}$ and $\mathrm{N}$ concentrations in forest soils in Spain after wildfires were reported by Knicker et al. (2005). Dai et al. (2006) described greater SOC and N stocks at sites with different fire treatments compared with unburnt controls in a temperate mixed-grass savanna.

In a recent study at adjacent grassland sites, stopping burning at natural grasslands for 22 years resulted in a SOC decrease of $23 \%$ (Knicker et al., 2008b). Compared with the results from our study, where a considerably bigger SOC decrease of $43 \%$ was shown in 30-year-old pine plantations, it is obvious that both stopping burning and enhanced degradation of SOM are responsible for the observed depletion of SOC. Furthermore, no alteration in $\mathrm{N}_{\text {tot }}$ stocks was found in grassland soils that were protected from burning for 22 years. Consequently, the considerable reduction of $\mathrm{N}_{\text {tot }}$ reported in our study can be attributed to the plantation of pines.

\section{Conclusions}

The grassland soils of the Brazilian Campos clearly showed a considerable decrease in SOM under plantations of Pinus taeda. This depletion is caused both by an enhanced degradation of SOM because of a reduced input of organic material and by stopping regular burning inside the plantations. Pine plantations in this region are primarily used for production of cellulose and harvested after $<30$ years and thus the observed decline of SOM probably cannot be balanced because of a long degradation period of recalcitrant pine litter. Thus, the $\mathrm{C}$ sequestration potential of the mineral soil is probably reduced. As soil fertility in the weathered grassland soils is associated mainly with SOM, the demonstrated decreases are likely to reduce availability and supply of nutrients in the mineral soil.

\section{Acknowledgements}

The authors would like to thank the staff of the Laboratoire de Biogeochimie des Milieux Continentaux from INRA for 
support with $\delta^{13} \mathrm{C}$ and lignin analysis and Petra Müller (TUM) for technical assistance. This project was partially financed by CAPES (Brazil) and DAAD (Germany).

\section{References}

Alvarez, R. \& Lavado, R.S. 1998. Climate, organic matter and clay content relationships in the Pampa and Chaco soils, Argentina. Geoderma, 83, 127-141.

Baldock, J.A., Oades, J.M., Waters, A.G., Peng, X., Vassallo, A.M. \& Wilson, M.A. 1992. Aspects of the chemical structure of soil organic materials as revealed by solid-state ${ }^{13} \mathrm{C}$ NMR spectroscopy. Biogeochemistry, 16, 1-42.

Behling, H. 1997. Late quaternary vegetation, climate and fire history of the Araucaria forest and Campo region from Serra Campo Gerais, Paraná, (South Brazil). Review of Palaeobotany and Palynology, 97, 109-121.

Birk, E.M. 1992. Nitrogen availability in radiata pine plantations on former pasture sites in southern New South Wales. Plant and Soil, 143, $115-125$.

Carvalho, P.C. de F. 2006. Access to Land, Livestock Production and Ecosystem Conservation in the Brazilian Campo Biome: The Natural Grasslands Dilemma. Food and Agriculture Organization of the United Nations, Rome.

Chen, X., Hutley, L.B. \& Eamus, D. 2005. Soil organic carbon content at a range of north Australian tropical savannas with contrasting site histories. Plant and Soil, 268, 161-171.

Dai, X., Boutton, T.W., Hailemichael, M., Ansley, R.J. \& Jessup, K.E. 2006. Soil carbon and nitrogen storage in response to fire in a temperate mixed-grass savanna. Journal of Environmental Quality, 35, 1620-1628.

Davis, M.R. 1995. Influence of radiata pine seedlings on chemical properties of some New Zealand montane grassland soils. Plant and Soil, 176, 255-262.

Dieckow, J., Mielniczuk, J., Knicker, H., Bayer, C., Dick, D.P. \& Kögel-Knabner, I. 2005. Composition of organic matter in a subtropical Acrisol as influenced by land use, cropping and $\mathrm{N}$ fertilization, assessed by CPMAS ${ }^{13} \mathrm{C}$ NMR spectroscopy. European Journal of Soil Science, 56, 705-715.

Dignac, M.-F., Bahri, H., Rumpel, C., Rasse, D.P., Bardoux, G., Balesdent, J. et al. 2005. Carbon-13 natural abundance as a tool to study the dynamics of lignin monomers in soil: an appraisal at the Closeaux experimental field (France). Geoderma, 128, 3-17.

Dümig, A., Schad, P., Kohok, M., Beyerlein, P., Schwimmer, W. \& Kögel-Knabner, I. 2007. A mosaic of nonallophanic Andosols, Umbrisols and Cambisols on rhyodacite in the southern Brazilian highlands. Geoderma, 145, 158-173.

Farley, K.A. \& Kelly, E.F. 2004. Effects of afforestation of a páramo grassland on soil nutrient status. Forest Ecology and Management, 195, 281-290.

Goldammer, J.G. 1993. Feuer in Waldökosystemen der Tropen und Subtropen. Birkhäuser Verlag, Basel, Boston.

Gonçalves, C.N., Dalmolin, R.S.D., Dick, D.P., Knicker, H., Klamt, E. \& Kögel-Knabner, I. 2003. The effect of $10 \%$ HF treatment on the resolution of CPMAS ${ }^{13} \mathrm{C}$ NMR spectra and on the quality of organic matter in Ferralsols. Geoderma, 116, 373-392.

Guo, L.B. \& Gifford, R.M. 2002. Soil carbon stocks and land use change: a meta analysis. Global Change Biology, 8, 345-360.
Hartge, K.H. \& Horn, R. 1989. Die Physikalische Untersuchung von Böden. Enke Verlag, Stuttgart.

Hedges, J.I. \& Ertel, J.R. 1982. Characterization of lignin by gas capillary chromatography of cupric oxide oxidation products. Analytical Chemistry, 54, 174-178.

Hedges, J.I. \& Mann, D.C. 1979. The characterization of plant tissues by their lignin oxidation products. Geochimica et Cosmochimica Acta, 43, 1803-1807.

Hueck, K. 1966. Die Wälder Südamerikas. Fischer Verlag, Stuttgart.

IPCC. 2007. Climate Change 2007: Mitigation. Contribution of Working Group III to the Fourth Assessment Report of the Intergovernmental Panel on Climate Change. Cambridge University Press, Cambridge.

IUSS Working Group WRB. 2006. World Reference Base for Soil Resources 2006. World Soil Resources Reports No. 103. Food and Agriculture Organization of the United Nation, Rome.

Jackson, R.B., Canadell, J., Ehleringer, J.R., Mooney, H.A., Sala, O.E. \& Schulze, E.D. 1996. A global analysis of root distributions for terrestrial biomes. Oecologia, 108, 389-411.

Johansson, M.-B., Kögel, I. \& Zech, W. 1986. Changes in the lignin fraction of spruce and pine needle litter during decomposition as studied by some chemical methods. Soil Biology and Biochemistry, 18, 611-619.

Knicker, H. 2007. How does fire affect the nature and stability of soil organic nitrogen and carbon? A review. Biogeochemistry, 85, 91-118.

Knicker, H., González-Vila, F.J., Polvillo, O., González, J.A. \& Almendros, G. 2005. Fire-induced transformation of C- and Nforms in different organic soil fractions from a Dystric Cambisol under a Mediterranean pine forest (Pinus pinaster). Soil Biology and Biochemistry, 37, 701-718.

Knicker, H., Almendros, G., González-Vila, F.J., González-Pérez, J.A. \& Polvillo, O. 2006. Characteristic alterations of quantity and quality of soil organic matter caused by forest fires in continental Mediterranean ecosystems: a solid-state ${ }^{13} \mathrm{C}$ NMR study. European Journal of Soil Science, 57, 558-569.

Knicker, H., Müller, P. \& Hilscher, A. 2007. How useful is chemical oxidation with dichromate for the determination of "Black Carbon" in fire-affected soils? Geoderma, 142, 178-196.

Knicker, H., Wiesmeier, M. \& Dick, D.P. 2008a. A simplified method for the quantification of pyrogenic organic matter in grassland soils via chemical oxidation. Geoderma, 147, 69-74.

Knicker, H., Nikolova, R., Hilscher, A., Dick, D.P. \& Dalmolin, R.S.D. 2008b. Alteration of quality and stability of organic matter in grassland soils of Southern Brazil highlands after ceasing biannual burning. Biogeochemistry, submitted.

Kögel-Knabner, I. 2002. The macromolecular organic composition of plant and microbial residues as inputs to soil organic matter. Soil Biology and Biochemistry, 34, 139-162.

Lal, R. 2004. Carbon sequestration in dryland ecosystems. Environmental Management, 33, 528-544.

Le Maitre, D.C. 1998. Pines in cultivation: a global view. In: Ecology and Biogeography of Pinus (ed. D.M. Richardson), pp. 407-431. Cambridge University Press, Cambridge.

Lilienfein, J., Wilcke, W., Ayarza, M.A., Vilela, L., Lima, S.d.C. \& Zech, W. 2000. Soil acidification in Pinus caribaea forests on Brazilian savanna Oxisols. Forest Ecology and Management, 128, 145-157. 
Martinelli, L.A., Pessenda, L.C.R., Espinoza, E., Camargo, P.B., Telles, E.C., Cerri, C.C. et al. 1996. Carbon-13 variation with depth in soils of Brazil and climate change during the Quaternary. Oecologia, 106, 376-381.

Nabinger, C., Moraes, A. \& Maraschin, G.E. 2000. Campo in Southern Brazil. In: Grassland Ecophysiology and Grazing Ecology (eds G. Lemaire, J. Hodgson, A. Moraes, C. Nabinger, P.C.F. Carvalho), pp. 355-376. CAB International, Wallingford, UK.

Nimer, E. 1979. Climatologia do Brasil. Fundação Instituto Brasileiro de Geografia e Estatística, Rio de Janeiro.

Overbeck, G.E., Müller, S.C., Fidelis, A., Pfadenhauer, J., Pillar, V.D., Blanco, C.C. et al. 2007. Brazil's neglected biome: The South Brazilian Campos. Perspectives in Plant Ecology, Evolution and Systematics, 9, 101-116.

Parfitt, R.L., Percival, H.J., Dahlgren, R.A. \& Hill, L.F. 1997. Soil and solution chemistry under pasture and radiata pine in New Zealand. Plant and Soil, 191, 279-290.

Paul, K.I., Polglase, P.J., Nyakuengama, J.G. \& Khanna, P.K. 2002. Change in soil carbon following afforestation. Forest Ecology and Management, 168, 241-257.

Ross, D.J., Tate, K.R., Scott, N.A., Wilde, R.H., Rodda, N.J. \& Townsend, J.A. 2002. Afforestation of pastures with Pinus radiata influences soil carbon and nitrogen pools and mineralization and microbial properties. Australian Journal of Soil Research, 40, 1303-1318.

Rumpel, C., Alexis, M., Chabbi, A., Chaplot, V., Rasse, D.P., Valentin, C. et al. 2006. Black carbon contribution to soil organic matter composition in tropical sloping land under slash and burn agriculture. Geoderma, 130, 35-46.

Schmidt, M.W. \& Noack, A.G. 2000. Black carbon in soils and sediments: analysis, distribution, implications, and current challenges. Global Biogeochemical Cycles, 14, 777-793.

Schmidt, M.W.I., Knicker, H., Hatcher, P.G. \& Kögel-Knabner, I. 1997. Improvement of ${ }^{13} \mathrm{C}$ and ${ }^{15} \mathrm{~N}$ CPMAS NMR spectra of bulk soils, particle size fractions and organic material by treatment with 10\% hydrofluoric acid. European Journal of Soil Science, 48, 319-328.

Scholes, M.C. \& Nowicki, T.E. 1998. Effects of pines on soil properties and processes. In: Ecology and Biogeography of Pinus (ed. D.M. Richardson), pp. 341-353. Cambridge University Press, Cambridge.

Staddon, P.L. 2004. Carbon isotopes in functional soil ecology. Trends in Ecology \& Evolution, 19, 148-154.

Steffens, M., Kölbl, A., Totsche, K.U. \& Kögel-Knabner, I. 2008. Grazing effects on soil chemical and physical properties in a semiarid steppe of Inner Mongolia (P.R. China). Geoderma, 143, 63-72.

Wolbach, W.S. \& Anders, E. 1989. Elemental carbon in sediments: determination and isotopic analysis in the presence of kerogen. Geochimica and Cosmochimica Acta, 53, 1637-1647.

Ziegler, F., Kögel, I. \& Zech, W. 1986. Alteration of gymnosperm and angiosperm lignin during decomposition in forest humus layers. Zeitschrift für Pflanzenernährung \& Bodenkunde, 149, 323-331.

Zinn, Y.L., Resck, D.V.S. \& Da Silva, J.E. 2002. Soil organic carbon as affected by afforestation with Eucalyptus and Pinus in the Cerrado region of Brazil. Forest Ecology and Management, 166, 285-294. 